\title{
Article \\ Comparing Bioeconomy Potential at National vs. Regional Level Employing Input-Output Modeling
}

\author{
Piotr Jurga ${ }^{1, *}$, Efstratios Loizou ${ }^{2}(\mathbb{D})$ and Stelios Rozakis ${ }^{3}(\mathbb{D}$ \\ 1 Department of Bioeconomy and Systems Analysis, Institute of Soil Science and Plant Cultivation, \\ State Research Institute (IUNG-PIB), 24-100 Pulawy, Poland \\ 2 Department of Regional Development and Cross Border Studies (RDCBS), University of Western Macedonia, \\ 50100 Kozani, Greece; eloizou@uowm.gr \\ 3 Bioeconomy and Biosystems' Economics Lab, School of Environmental Engineering, Technical University \\ of Crete, 73100 Chania, Greece; srozakis@isc.tuc.gr \\ * Correspondence: pjurga@iung.pulawy.pl; Tel.: +48-81-4786-797
}

Citation: Jurga, P.; Loizou, E.; Rozakis, S. Comparing Bioeconomy Potential at National vs. Regional Level Employing Input-Output Modeling. Energies 2021, 14, 1714. https://doi.org/10.3390/en14061714

Academic Editor: Ricardo J. Bessa

Received: 16 February 2021

Accepted: 14 March 2021

Published: 19 March 2021

Publisher's Note: MDPI stays neutral with regard to jurisdictional claims in published maps and institutional affiliations.

Copyright: (c) 2021 by the authors. Licensee MDPI, Basel, Switzerland. This article is an open access article distributed under the terms and conditions of the Creative Commons Attribution (CC BY) license (https:/ / creativecommons.org/licenses/by/ $4.0 /)$.

\begin{abstract}
The support of economic sectors that exploit natural bio-based resources in a particular region is an opportunity to benefit from local potentials in terms of sustainability, employment, output, and household income. Hence a relevant question emerges, namely, how can bioeconomy sectors be adequately supported? Within this context, another issue is whether the bioeconomy development strategy at a national level should be the same as that at a regional level. To address these issues, in the current study a comparison was made between the bioeconomy sectors at the country level based on the case study of Poland and one of the poorest regions in the European Union-the Lubelskie Region. A regional input-output model was built for the regional economy and compared with the national model. The bioeconomy-oriented regional input-output table was built by applying a hybrid regionalization method, combining non-survey techniques and a questionnaire survey that was carried out in companies of mixed bio-based sectors. Sectoral linkages, such as multipliers and elasticities, indicate notable differences among the bio-based sectors' potentials of the regional and national economies. Therefore, a bioeconomy development strategy should be seen to differ at national and regional levels.
\end{abstract}

Keywords: bioeconomy; input-output; Poland; regional modeling

\section{Introduction}

\subsection{The Concept of Bioeconomy}

It has been identified that the bioeconomy is not merely another material sector but concerns industrial value creation based on biological resources and waste, and as such it is linked to many scientific fields and disciplines [1]. Nearly ten years ago, in 2012, the strategy "Innovating for Sustainable Growth-a Bioeconomy for Europe" was adopted at the European Union level. This document was a response to many of the problems faced by both Europe and the world at that time [2]. In 2017, this strategy was updated in a document entitled "Review of the 2012 European Bioeconomy Strategy" based on the current definition of the economy and the main objective of changing social preferences and transforming countries' economies into more innovative, resource-efficient, and competitive ones. An innovative economy should reconcile food security with the preservation and efficient use of renewable resources, including preservation of the natural environment [3]. We can identify many scientific studies assessing the contribution of bio-based activities to the achievement of the aforementioned objectives: the evaluation of the possibility of producing bioethanol from sorghum [4], the economic analysis of the use of plants in the bioeconomy [5], the evaluation of the possibility of using natural fertilizers for bioenergy [6], or the possibility of using straw for energy purposes [7]. 
In addition to establishing definitions, setting targets, and conducting research to improve the knowledge of the bioeconomy, attempts have been made to identify indicators by which the state of the bioeconomy in the European Union, individual Member States, or at a regional level can be estimated. Independent scientific bodies (e.g., joint research centers) are making significant efforts in this area: studying the share of bio-products and their impact on bioeconomy sectors [8,9], estimating the production and processing of biomass by individual sectors of the bioeconomy [10], building tools to monitor the bioeconomy [11,12], or assessing employment in bioeconomy sectors [13]. In addition to estimating and analyzing indicators for the bioeconomy, attempts have been undertaken to use more advanced methods for quantitative impact assessment. One of these methods is input-output analysis, taking into account knowledge and data on the share of individual economic sectors using bio-based intermediates [14].

\subsection{Bioeconomy at National and Regional Level in the European Union}

In response to the efforts of the European Union, several Member States have established a strategy for developing the bioeconomy. The Member States of the European Union are involved in the development of the bioeconomy, as confirmed by directly developed strategies or related initiatives. Scientific research and economic analysis support policy authorities that develop strategies for bioeconomy development: e.g., in Germany [15], Latvia [16,17], Finland [18], Spain [19], Ireland [20] or Poland [21]. As a result of the disparities between regions, particularly in countries with a relatively large area and population, a national strategy or support for the development of the bioeconomy may not be sufficient. Elements such as the terrain, availability of biomass, human resources, or innovation may influence the level of development of different economic sectors and their interlinkages [22]. The majority of the European Union's regions are involved in activities aiming to contribute to the development of the bioeconomy. Nevertheless, only around $36 \%$ of the regions do this in an effective and efficient form [23]. In support of these objectives, actions can be taken to increase the importance of sectors that supply and sustainably process biomass, creating bio-products, ensuring sustainability, and moving away from fossil fuels. It has been recognized that actions initiated at the regional level can make a key contribution to the development of the bioeconomy [24,25], namely, the smart specialization strategy as a component of regional policies in Poland and elsewhere. Although in most Central and Eastern European countries, such as Poland, initiatives are being established to develop and monitor the bioeconomy, there is still a lack of tools to identify key economic sectors for the development of the bioeconomy. The majority of transformations towards greater use of biomass and the development of the bioeconomy are being carried out at a local and regional level [23]. Considering the abovementioned, the first challenge of this work was to determine the shares of bioeconomy sectors in the mixed bio-based sectors of a regional economy and then to disaggregate them. To achieve this objective, surveys were designed and carried out in the companies of the sectors concerned. The second objective of the study was to evaluate and compare the role and importance of particular sectors of the bioeconomy for the economy of an exemplary region in eastern Poland and the national economy. A comparison of the importance of a given sector for the development of the bioeconomy may provide an answer to the question of whether the development strategy should be identical or similar at the national and regional levels. These results may have use in providing information to decision-makers, regarding whether it is more efficient to design bioeconomy strategies at the national or regional level, after taking into account the peculiarities of regional economies. This work extends previous research on Polish regional input-output (I-O) analysis, further detailing the number of sectors' [26] attempts and their disaggregation to derive bio-based sectors with the use of original information by means of surveys to complement statistics with superior data. 


\subsection{Bioeconomy during the COVID-19 Pandemic}

At the beginning of 2020, the pandemic outbreak caused by COVID-19 resulted in a production slowdown. Although the policy makers' reactions were diverse throughout the world, overall, the pandemic had a significant impact on the functioning of countries' economies, existing supply chains, and societies globally. In addition to the factors limiting the activity of the economy resulting from isolation during the pandemic, another issue is the lack of availability of intermediate goods used for production. When supply chains are disrupted, many crucial products, e.g., medical products, cannot be fabricated. Problems also emerge with ensuring food security.

There is an ongoing discussion on the effect of the pandemic on national economies [27]. Despite the lack of available results on the impact of COVID-19 on the bioeconomy of individual European Union countries, announcements are being published relating to actions taken by Member States in connection with the crisis in national economies [28]. In addition, opportunities are anticipated for the development of the bioeconomy as part of the new green deal. Each crisis results in increased innovation and changes the behavior of existing businesses [29]. On the one hand, the COVID-19 crisis is causing a reduction in economic growth and is, therefore, a temptation to abandon the ambitious plans to speed up the transition to a zero-carbon economy. On the other hand, the pandemic provides opportunities and support for individual sectors of the economy through, for example, the recovery fund [30]. Based on published data, it is observed that some sectors of the economy experience the effects of the crisis mostly as a result of quarantine measures, reduced migration, and falling demand. Tourism and related services have been particularly affected by the crisis [31].

Relevant research has shifted from the global impact analysis of disasters to that devoted to disease and virus pandemics, with recent publications both at a national level, namely in China and Japan [32,33], and the global level [34]. In this regard, inputoutput analysis aims to comprehend the linkages between sectors and to determine the direct and indirect impact on the economy $[21,35,36]$ from behavioral impacts on the economic structure (i.e., transport or commuting preferences) and public policies (measures against supply chain disruptions restraining international trade or public investments in infrastructure by means of the European recovery fund) [37,38].

These tools can also be used ex ante to appreciate alternative pathways rather than the return to the business-as-usual aim of catching up and thus causing a boost in production, which will consequently intensify polluting activities. The UN Secretary General urged in favor of the former attitude by developing an economy compatible with more sustainable and resilient societies. Practically all regions of Europe, Poland and the Lubelskie Region in particular, possess biomass resources that can be used and processed efficiently. This capability may help to overcome the crisis and to enforce resilience of the local economy. For this purpose, in this study, we aimed to compare ad hoc input-output tables explicating the bioeconomy at the national and the regional level.

In the next section, the input-output methodology is presented, in addition to the regionalization of intersectoral transaction tables. Then, the regional bioeconomy integration to the I-O tables is detailed for the case study. Results reveal the structural peculiarities in various sectors and levels of the economy in Poland. Discussion and conclusive thoughts complete the paper.

\section{Materials and Methods}

\subsection{Modelling Framework of the Study}

As mentioned above, one of the main objectives of this study was to examine the bioeconomy at the regional level, identifying the most dynamic and influential sectors for its development. Identifying the structure and transactions between sectors in the regional economy enables the most influential sectors of the bioeconomy to be identified and captures their economy-wide impacts. The tool chosen to assess the relationship between the sectors of the bioeconomy and their impact on the whole economy is a general 
equilibrium-type model input-output (I-O) analysis. I-O models have been previously used to assess the impact of the bioeconomy [25], and in particular the impact of renewable energy sources [35,39] or bioeconomy development [40], on the economy at regional or national levels. The use of this method makes it feasible to obtain results that will allow the assumed objectives to be achieved. Furthermore, the use of the I-O model makes it possible to evaluate and compare the importance of a given sector of the bioeconomy at a national and regional level. As a result of this analysis, output, employment, and household income I-O multipliers and elasticities for each sector of the economy were calculated. A comparison of the importance of a given sector for the development of the bioeconomy may provide an answer to the question of whether development strategies should be identical at the national and regional level.

\subsection{Input-Output Model Basic Framework}

The analytical framework for I-O analysis was originally invented by Wassily Leontief, who received the Nobel Prize for developing this method in 1973. This method is used in many macroeconomic analyses to analyze individual sectors of the economy in relation to the whole economy. In general terms, the model consists of a system of linear equations that describe purchases and sales between sectors of the economy [36]. The basic assumptions of the input-output analysis have been developed over time and adapted to many other aspects and areas, such as climate change [41], waste management [42], transportation [43], water management, resource management [44], and the bioeconomy [20,21]. Despite the well-known limitations of the model, such as fixed coefficients, linearity, and simplifications, it has been widely used in many countries. The limitations and the foundation of the model are described in Miller and Blair [36].

The structure of the model is based on three matrices, the data from which are used to obtain final calculations reflecting the dynamics and importance of the sector. These matrices are the transactions matrix, the direct requirements matrix, and the Leontief inverse matrix. Each sector of the economy is defined by the transaction row and column. Total gross output of each sector is the sum of intermediate demand and final demand. Consumption, exports, and the remainder of the variables determine the final demand. The column of transactions of a given sector is the sum of intermediate inputs and so-called primary inputs: imports, compensation of employees, and other variable inputs. The direct and total demand of economic sectors is calculated using the direct requirements matrix and the Leontief inverse. A mathematical note describing the steps in the transition from the monetary transactions included in the I-O symmetric matrix to the calculated multipliers and elasticities is described in Table 1 below. A more detailed description of the individual steps can be found in $[35,45]$.

Table 1. Input-output analysis, main steps [35,45].

\begin{tabular}{|c|c|c|}
\hline Input-Output Analysis-Mathematical Notations & Description & No. \\
\hline $\begin{array}{l}\qquad X_{i}=\sum_{j}^{n} X_{i j}+C_{i}+E_{i}+O F_{i} \\
X_{i} \text {-total gross output of each sector } i ; \sum_{j}^{n} X_{i j} \text {-sum of intermediate } \\
\text { demand; } C_{i} \text {-consumption; } E_{i} \text { - exports; OF } F_{i} \text {-other final demand } \\
\text { variables; }\end{array}$ & $\begin{array}{l}\text { Equation describing transactions for } \mathrm{n} \\
\text { economic sectors (rows transactions) }\end{array}$ & $(1)$ \\
\hline $\begin{array}{c}X_{j}=\sum_{i}^{n} X_{i j}+L_{j}+M_{j}+O P_{j} \\
X_{j} \text {-total inputs of sector } j ; \sum_{i}^{n} X_{i j} \text {-sum of sector } j \text { intermediate inputs; } \\
L_{j} \text {-sector compensation of employees; } M_{j} \text {-sector } j \text { imports; OP }- \text { other } \\
\text { primary inputs variables; }\end{array}$ & $\begin{array}{l}\text { Equation describing transactions for } \mathrm{n} \\
\text { economic sectors (columns transactions) }\end{array}$ & $(2)$ \\
\hline
\end{tabular}


Table 1. Cont

\begin{tabular}{|c|c|c|}
\hline Input-Output Analysis-Mathematical Notations & Description & No. \\
\hline $\begin{array}{l}\qquad a_{i j}=\frac{X_{i j}}{X_{j}} \\
a_{i j} \text {-coefficient of the input requirements for the production per unit of } \\
\text { final demand; } X_{i j} \text {-amount of inputs a sector } j \text { purchases from selling } \\
\text { sector } i ; X_{j} \text { - total output of sector } j ;\end{array}$ & Equation for deriving direct coefficients & (3) \\
\hline $\begin{array}{c}\mathrm{X}=\mathrm{AX}+\mathrm{Y} \\
\mathrm{A} \text {-direct requirements matrix, } \mathrm{X} \text {-vector of total output, } \mathrm{Y} \text {-vector of } \\
\text { final demand, }\end{array}$ & The Leontief model in its general form & (4) \\
\hline $\mathrm{X}-\mathrm{AX}=\mathrm{Y},(\mathrm{I}-\mathrm{A}) \mathrm{X}=\mathrm{Y}$ & Determining final demand & (5) \\
\hline $\begin{array}{c}\mathrm{X}=(\mathrm{I}-\mathrm{A})^{-1} \mathrm{Y} \\
(\mathrm{I}-\mathrm{A})^{-1} \text {-Total Requirements Matrix, alternatively_Leontief Inverse }\end{array}$ & Determining Leontief's Inverse & (6) \\
\hline
\end{tabular}

\subsection{Input-Output Modelling at National and Regional Scale including Bioeconomy Sectors}

As a result of the lack of availability of regional I-O tables, there is a need to construct one, a task that extensively appears in the international literature [45-49]. The construction of a regional I-O table can be performed by applying a number of non-survey techniques (regionalization techniques). In the current case, the Generation of Regional Input-Output Tables (GRIT) technique was used, as originally developed by Jensen et al. [50]. A modified version was later developed and adopted by Mattas et al. [49]. The GRIT technique is a partial survey hybrid technique that offers the user the ability to insert superior data for sectors with regional significance in the model. Thus, a regional I-O table for the Polish region was constructed using the national table and superior data (primary and secondary). For this analysis, the Flegg Location Quotient (FLQ) formula was used, which has been included in a number of studies in the literature $[46,51]$. The whole procedure consists of a number of steps. Based on a national matrix of cross-industry transactions, sectoral aggregation and reallocation of foreign trade are initially carried out. Then, a matrix of direct national requirements is created, together with sectoral aggregation. Finally, a regional symmetric I-O matrix is obtained and then used to calculate the multipliers and elasticities [49]. The FLQ method has an advantage over other approaches proposed in the literature, namely, Simple Location Quotient (SLQ) or Cross Industry Location Quotient (CILQ). The FLQ method takes into account the relative size of the region, and the relative size of the supply and of the purchasing sector. One of the key elements of the FLQ method is the determination of the unknown parameter $\delta$. This parameter is used for adjustments of import values for the region. Based on the research papers of Flegg and Thomo [51-53], the most appropriate value for this parameter was identified in this work, taking into account the characteristics of the Lubelskie Region.

The sectors of the national economy presented in the I-O symmetric matrix do not offer a detailed analysis of all economic activities related to the production and processing of biomass. Therefore, there is a need to adapt the input-output symmetric matrix to separate the biomass production and processing sectors. For Poland, this analysis of identification and separation from mixed bio-based sectors, and biomass-processing production sectors, has been performed [21], applying the method proposed by the Joint Research Centre [8]. The aim of this article is not to present the status of sectors that produce and process biomass in Poland (pure and mixed bio-based sectors). Nevertheless, the input-output analysis was performed for comparison purposes, using updated input data, first, as one of the steps to obtain results for the regional economy and, second, to enable comparison of the importance of bioeconomy sectors at national and regional level. If a sector does not exist in the economy, there is a need to incorporate it in the input-output table. If, in contrast, a sector is of marginal importance for the conducted analysis, it is merged with other sectors. Following the completion of the disaggregation process, the transactions of the bioeconomy sectors that were classified as mixed were corrected. As a percentage, 
these were split between the biomass production sector and the remainder (e.g., production of textiles, wearing apparel, or furniture). The percentage distribution for Poland was based on published data, and then cross-industry transactions were corrected based on expert reviews.

After creating a new symmetric I-O matrix, the input-output analysis described in the section above was carried out: (1) for Poland (Table 1) and (2) for the Lubelskie Region as a case study example (GRIT with FLQ). The entire calculation procedure, both for Poland and for the I-O matrix for the Lubelskie Region, was carried out using code written in the GAUSS software. Performing this analysis made it possible to identify, among other things, the key sectors of the bioeconomy at regional level, in terms of output, employment, and household income. The obtained linkage coefficients for the Lubelskie regional economy were compared with the results obtained for Poland to identify the differences that exist and possibly draw attention to a different approach to develop the bioeconomy at a different scale.

\subsection{Bioeconomy in the Lubelskie Region}

One of the objectives of this study was to determine whether the dynamics and importance of national bioeconomy sectors is different from those of regional bioeconomy sectors. Poland is administratively divided into sixteen regions. The Lubelskie Region, located in the east of Poland, on the peripheries of the European Union, was chosen as an illustrative region. The analyzed region is the third-largest in Poland in terms of area. In comparison to other regions, it has an average population and low population density. Agricultural land in the Lubelskie Region accounts for about 70\%, and forest land for about $25 \%$ of the area [54]. The average monthly salary in the Lubelskie Region constitutes $88.48 \%$ of the national average salary, and the expenditure on research and development activities accounts for only $3.14 \%$ of the national expenditure. Around $13 \%$ of Polish farms are located in the Lubelskie Region. The distribution of gross value added by type of activity for Lubelskie is as follows: primary sectors $5.3 \%$; industry $21.2 \%$; trade, repair of motor vehicles, transportation and storage $28 \%$; construction $7.3 \%$; financial and insurance activities, real estate activities $10.2 \%$; other $28 \%$ [54]. The bioeconomy is the principal area of smart specialization in the Lubelskie Region. It was included in the document of the Regional Innovation Strategy for the Lubelskie Region until 2020 [55]. The abovementioned discipline is a strategic area for the Lubelskie Region due to the scientific and technological potential of the region, the high potential for export of bio-products, and the availability of biomass. The following economic sectors, which are important for the development of the bioeconomy, have been supported in recent years in the Lubelskie Region: agri-food, energy, pharmaceutical, chemical, paper, wood, and furniture [56]. The Lubelskie Region was chosen for this analysis as a case study due to its great potential for the development of the bioeconomy. Moreover, another important aspect is that this region is one of the most impoverished in Poland and the European Union. The outcome of any analysis which is likely to contribute to a faster and better development of the Lubelskie Region would be a positive example for other regions.

\subsection{Model Data Requirements: Collection of Primary and Secondary Data}

One of the most essential inputs used for the analysis was the national symmetric I-O table at basic prices in 2015 published by Statistics Poland [57]. The matrix used was initially constructed from 77 sectors which, as a result of disaggregation and aggregation processes, were reconstructed, ultimately obtaining 79 sectors of economic activity, including bioeconomy sectors. The created bioeconomy sectors, based on the procedure [8] proposed by the Joint Research Centre (JRC), are presented in Table 2. The percentage of the mixed biomass-based sectors of the Polish economy was taken from the analysis carried out by the JRC. The last three columns of Table 2 present the shares of mixed sectors based on biomass processing for the EU-28 economy, Poland, and the Lubelskie Region. 
Table 2. Fully and mixed bio-based sectors' share in Poland and the Lubelskie Region.

\begin{tabular}{|c|c|c|c|c|c|c|}
\hline Number & $\begin{array}{l}\text { NACE } \\
\text { Code }\end{array}$ & Sector & Sector (Acronym) & $\begin{array}{l}\text { EU-28 } \\
(\%)[1]\end{array}$ & $\begin{array}{l}\text { Poland }(\%) \\
{[1,2]}\end{array}$ & $\begin{array}{c}\text { Lubelskie } \\
\text { Region (\%) [2] }\end{array}$ \\
\hline 1 & 01 & $\begin{array}{c}\text { Crop and animal production, } \\
\text { hunting and related service } \\
\text { activities }\end{array}$ & Agriculture & & & \\
\hline 2 & 02 & Forestry and logging & Forestry & & & \\
\hline 3 & 03 & Fishing and aquaculture & $\begin{array}{l}\text { Fisheries (sea, } \\
\text { aquaculture) }\end{array}$ & & & \\
\hline 4 & 10 & Manufacture of food products & Food products & & & \\
\hline 5 & 11 & Manufacture of beverages & Beverages & & & \\
\hline 6 & 12 & Manufacture of tobacco products & Tobacco & & & \\
\hline 7 & (\%) 13 & Manufacture of textiles & Bio-based textiles & 27.04 & 13.16 & 11.83 \\
\hline 8 & (\%) 14 & Manufacture of wearing apparel & $\begin{array}{l}\text { Bio-based Wearing } \\
\text { apparel }\end{array}$ & 40.98 & 41.9 & 36.66 \\
\hline 9 & 15 & $\begin{array}{l}\text { Manufacture of leather and } \\
\text { related products }\end{array}$ & $\begin{array}{l}\text { Leather and related } \\
\text { products }\end{array}$ & & & \\
\hline 10 & 16 & $\begin{array}{l}\text { Manufacture of wood and of } \\
\text { products of wood and cork, except } \\
\text { furniture; manufacture of articles } \\
\text { of straw and plaiting materials }\end{array}$ & Wood products & & & \\
\hline 11 & 17 & $\begin{array}{l}\text { Manufacture of paper and paper } \\
\text { products }\end{array}$ & $\begin{array}{l}\text { Paper and paper } \\
\text { products }\end{array}$ & & & \\
\hline 12 & $(\%) 20$ & $\begin{array}{l}\text { Manufacture of chemicals and } \\
\text { chemical products }\end{array}$ & $\begin{array}{c}\text { Bio-based } \\
\text { chemicals (excl. } \\
\text { Biofuels) }\end{array}$ & 7.65 & 2.91 & 0.01 \\
\hline 13 & (\%) 20 & $\begin{array}{l}\text { Manufacture of other organic } \\
\text { basic chemicals }\end{array}$ & Bioethanol & $3.61^{\mathrm{a}}$ & $2.64^{b}$ & 0.71 \\
\hline 14 & (\%) 20 & $\begin{array}{l}\text { Manufacture of other chemical } \\
\text { products n.e.c. }\end{array}$ & Biodiesel & $10.01^{\mathrm{c}}$ & $4.78^{b}$ & 0.63 \\
\hline 15 & (\%) 21 & $\begin{array}{l}\text { Manufacture of basic } \\
\text { pharmaceutical products and } \\
\text { pharmaceutical preparations }\end{array}$ & $\begin{array}{c}\text { Bio-based } \\
\text { pharmaceuticals }\end{array}$ & 49.31 & 49.37 & 24.38 \\
\hline 16 & (\%) 22 & $\begin{array}{l}\text { Manufacture of rubber and plastic } \\
\text { products }\end{array}$ & $\begin{array}{l}\text { Bio-based plastics } \\
\text { and rubber }\end{array}$ & 4.62 & 6.13 & 1.22 \\
\hline 17 & (\%) 31 & Manufacture of furniture & Bio-based furniture & 43.68 & 44.74 & 45.33 \\
\hline 18 & (\%) 35 & $\begin{array}{l}\text { Electricity, gas, steam and air } \\
\text { conditioning supply }\end{array}$ & Biogas & $4.72^{\mathrm{d}}$ & $0.22^{\mathrm{e}}$ & $0.32^{\mathrm{e}}$ \\
\hline 19 & (\%) 35 & $\begin{array}{l}\text { Electricity, gas, steam and air } \\
\text { conditioning supply }\end{array}$ & Biomass & & $1.37^{\mathrm{e}}$ & $0.18^{\mathrm{e}}$ \\
\hline
\end{tabular}

Source: Data portal of agro-economics Modelling_DataM. Available online: https://datam.jrc.ec.europa.eu/datam/mashup/ BIOECONOMICS/index.html (accessed on 19 March 2021) (1) and own study and analysis (2); \%-the bio-based share of a given sector (calculated as in Equation (7)); ${ }^{\mathrm{a}} \%$ of 20.14; $\mathrm{b} \%$ of $20 ;^{\mathrm{c}} \%$ of $20.59 ;^{\mathrm{d}} \%$ of 35.11 (Bio-based electricity); ${ }^{\mathrm{e}} \%$ of 35.

The percentage share for the Lubelskie Region was estimated from the questionnaire data collected from businesses, expert opinions, and financial reports of companies. The greatest effort and challenge in obtaining data was to conduct surveys in companies classified as mixed sectors. The survey provided information on the production process, type and share of products, type of intermediates used in production, sales, and many 
factors. Based on the surveyed data, the following equation was used to calculate the share of biomass in a given sector ([9] with added modifications):

$$
\mathrm{BBS}_{\mathrm{i}, \mathrm{L}, 2018}=\frac{\sum_{\mathrm{j}=1}^{\mathrm{n}} \mathrm{bbs}_{\mathrm{j}} \times \text { Production value }_{\mathrm{j}, \mathrm{L}, \mathrm{k}}}{\sum_{\mathrm{j}=1}^{\mathrm{n}} \text { Production value }_{\mathrm{j}, \mathrm{k}, \mathrm{l}}}
$$

where $\mathrm{BBS}_{\mathrm{i}, \mathrm{k}, \mathrm{l}}$ is the bio-based share of sector $\mathrm{i}$ (Nomenclature of Economic Activities NACE Rev. 2), in the Lubelskie Region (L) in year 2018; $b b_{j}$ is the bio-based share of products of company $j$, given that sector $i$ manufactures $j=n$ companies. Bio-based shares vary from 0 for companies that do not incorporate biomass to 1 for those that use only biomass for production; Production value $j, k, 1$ is the production value of a company $j$, in the Lubelskie Region (L) in year 2018.

All of the mixed bio-based sectors were included in the survey (percentage out of total number of surveyed companies): textiles (percentage $=13.95 \%$ ), wearing apparel $(16.28 \%)$, furniture $(18.6 \%)$, chemicals $(11.63 \%)$, pharmaceuticals $(6.98 \%)$, plastics and rubber $(11.63 \%)$. The approximate location of the surveyed companies is illustrated in Figure 1.

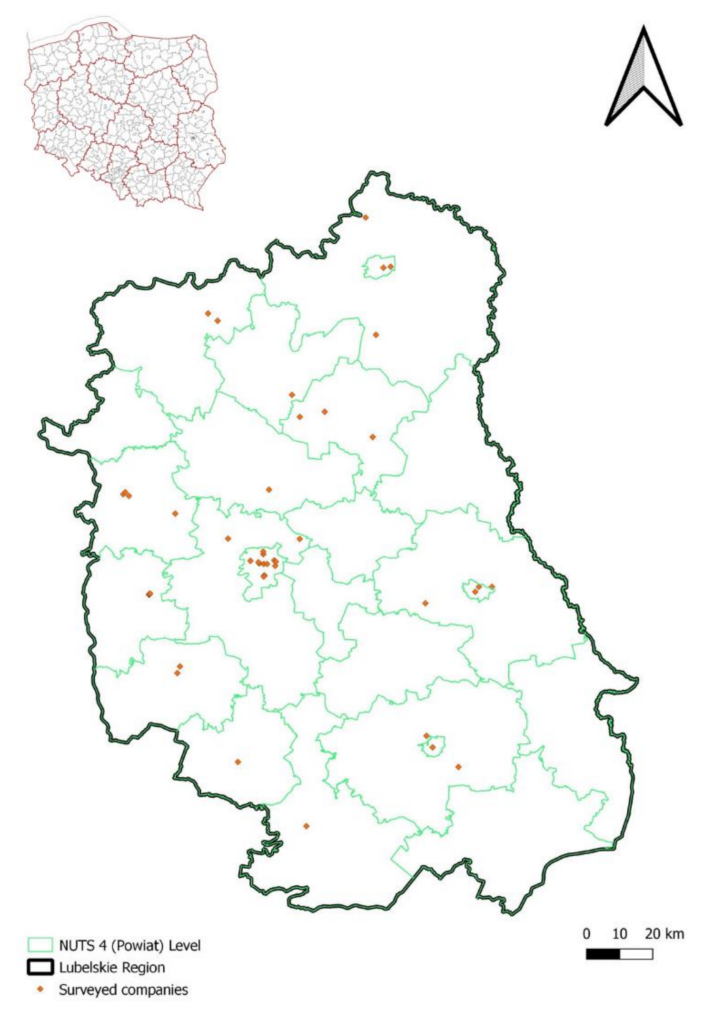

Figure 1. Map of the Lubelskie Region with the location of surveyed companies.

In addition, surveys were carried out in the bio-refineries in the Lubelskie Region producing bioethanol and biodiesel, and in biogas plants located in the region. Based on the surveyed data, expert opinions, and data from financial reports, nine new bioeconomy sectors were created, separate from mixed sectors. The share for sectors such as bioethanol, biodiesel, biogas, or electricity production (biomass) could not be compared with each other (European Union versus Poland or the Lubelskie Region) due to different calculation methods used. As can be seen in Table 2, the bio-based share is lower in the Lubelskie Region in comparison with Poland or the European Union. Lower shares of mixed biobased sectors may result from the fact that the Lubelskie Region is one of the poorest regions in Europe. Research and development is related to the companies' expenditure. 
The regional transaction matrix for the Lubelskie region was created using the GRIT technique and the FLQ formula, following the steps described in Mattas et al. 2006 [49]. The FLQ formula used the employment data published by Statistics Poland [58].

Finally, a matrix of regional transactions with the bioeconomy sectors was constructed for the Lubelskie Region. The matrix consisted of a total of 79 economic sectors. Among these, 18 sectors of the bioeconomy were separated. Applying the input-output model and the procedure described above resulted in obtaining multipliers and elasticities, which illustrate the interlinkages between the sectors of the regional economy. As a result of the analysis, Leontief's inversion, multipliers, and flexibility coefficients for gross output, employment, and household income were calculated for each sector. The direct and indirect impacts of a sector of the economy on the economy of the exemplary region were determined. Further, the prospective sectors of the bioeconomy in the region were identified in terms of gross output, employment, and household income, which could stimulate the region's economy. Finally, the results obtained were compared with the structure of significance of the bioeconomy sectors at the national level (Poland). A description of the results obtained is provided in the next section.

\section{Results}

In addition, as mentioned above, final calculations resulted in interesting outcomes concerning the relationships between the bioeconomy sectors and their potential, both at national and regional levels. Multipliers and elasticities for the regional and national economy were calculated, and are shown in Table 3. The higher the multiplier, the greater the impacts, both direct and indirect, on the national or regional economy.

Table 3. Input-output multipliers of the Polish and Lubelskie Region bioeconomy sectors (output, employment, and income).

\begin{tabular}{|c|c|c|c|c|c|c|c|c|c|c|c|c|c|}
\hline No. & Sector & OMP & $\mathbf{R}$ & OML & $\mathbf{R}$ & EMP & $\mathbf{R}$ & EML & $\mathbf{R}$ & IMP & $\mathbf{R}$ & IML & $\mathbf{R}$ \\
\hline 1 & Agriculture & 1.981 & 12 & 1.122 & 67 & 1.291 & 68 & 1.052 & 69 & 2.668 & 10 & 1.146 & 55 \\
\hline 2 & Forestry & 1.842 & 32 & 1.160 & 56 & 1.690 & 43 & 1.137 & 59 & 1.600 & 54 & 1.117 & 63 \\
\hline 3 & Fishing & 1.113 & 79 & 1.181 & 50 & 1.381 & 64 & 1.572 & 20 & 1.509 & 60 & 1.563 & 20 \\
\hline 4 & Food products & 2.278 & 2 & 1.391 & 17 & 5.547 & 2 & 3.132 & 1 & 2.693 & 9 & 1.390 & 30 \\
\hline 5 & Beverages & 2.179 & 4 & 1.165 & 54 & 5.334 & 4 & 1.870 & 14 & 2.700 & 8 & 1.156 & 54 \\
\hline 6 & Tobacco products & 1.541 & 58 & 1.126 & 65 & 5.474 & 3 & 2.428 & 7 & 2.052 & 25 & 1.138 & 57 \\
\hline 7 & Bio-based Textiles & 1.304 & 75 & 1.676 & 6 & 1.497 & 57 & 1.971 & 11 & 1.723 & 43 & 4.958 & 4 \\
\hline 8 & Bio-based Wearing apparel & 1.270 & 77 & 1.153 & 59 & 1.231 & 74 & 1.157 & 53 & 1.271 & 72 & 1.126 & 61 \\
\hline 9 & Leather products & 1.365 & 72 & 1.312 & 25 & 1.589 & 51 & 1.369 & 34 & 1.709 & 45 & 1.370 & 33 \\
\hline 10 & Wood products & 2.153 & 6 & 1.315 & 23 & 2.129 & 28 & 1.299 & 39 & 2.533 & 12 & 1.487 & 23 \\
\hline 11 & Paper and products & 1.865 & 28 & 1.349 & 20 & 2.852 & 15 & 1.558 & 21 & 2.553 & 11 & 1.577 & 19 \\
\hline 12 & Biochemicals & 1.315 & 74 & 1.240 & 39 & 2.678 & 17 & 1.200 & 48 & 2.153 & 22 & 1.306 & 41 \\
\hline 13 & Bioethanol & 1.621 & 48 & 1.232 & 40 & 3.992 & 5 & 2.635 & 4 & 3.034 & 3 & 1.383 & 31 \\
\hline 14 & Biodiesel & 1.621 & 49 & 1.262 & 36 & 3.987 & 6 & 2.650 & 3 & 3.031 & 4 & 1.467 & 24 \\
\hline 15 & Bio-Pharmaceutical products & 1.403 & 68 & 1.282 & 29 & 2.631 & 19 & 2.041 & 10 & 1.983 & 29 & 1.449 & 25 \\
\hline 16 & Bio-based Rubber and plastic products & 1.716 & 39 & 1.683 & 3 & 1.971 & 32 & 2.600 & 5 & 1.937 & 31 & 2.935 & 11 \\
\hline 17 & Bio-based furniture & 2.081 & 8 & 1.228 & 42 & 1.806 & 36 & 1.207 & 46 & 1.911 & 33 & 1.191 & 49 \\
\hline 18 & Bio-based electricity (agriculture-biogas) & 1.960 & 14 & 1.206 & 45 & 3.370 & 9 & 1.451 & 27 & 2.360 & 15 & 1.224 & 48 \\
\hline 19 & Bio-based electricity (from biomass) & 1.946 & 15 & 1.212 & 44 & 3.324 & 10 & 1.941 & 12 & 2.342 & 17 & 1.243 & 45 \\
\hline
\end{tabular}

OMP = Output Multipliers (Poland); OML = Output Multipliers (Lubelskie Region); EMP = Employment Multipliers (Poland); EML = Employment Multipliers (Lubelskie Region); IMP = Income Multipliers (Poland); IML = Income Multipliers (Lubelskie Region); R = Rank.

It is worth noting that national output multipliers are higher than regional ones, with a few exceptions (e.g., the fisheries sector). Due to the size and diversity of the economy, national and regional multipliers cannot be compared, so we focus on comparing the ranking of individual sectors.

In terms of output potential, pure bioeconomy sectors in Poland are ranked higher than those of the Lubelskie Region. However, mixed bio-based sectors have a more favorable ranking for the examined region (e.g., bio-based textiles or bio-based rubber and plastic rubber). The only exception is the bio-furniture sector, which has a high output multiplier rank for Poland and relatively low rank for the Lubelskie region. National bioeconomy 
sectors, in terms of output multiplier, such as food (rank $=2$ ), beverages $(4)$, bio-based furniture (8), agriculture (12), and agricultural biogas (14) are very high in the ranking. In the case of the economy of the Lubelskie Region, sectors such as bio-based rubber and plastic products (rank $=3$ ), bio-textiles (6), and food products (17) have a high ranking. The high position of mixed bio-based sectors in the Lubelskie Region may be caused by the limited number of companies which have a specific developed production. With a larger sample, as is the case with the national economy, mixed bioeconomy sectors are probably less developed.

Based on Table 3 values, it can be noted that the agricultural sector output multiplier in Poland has a high ranking with a high value (1.981), although the corresponding regional multiplier has a low ranking (1.122). This means an increase of one euro in the final demand of agriculture in the Lubelskie Region, increases the total output of the regional economy by 1.122 euro, and that of Poland by 1.981. As an example, the agricultural sector at national and regional levels may have a different percentage structure of output multipliers (Figure 2). Taking into account the direct and indirect impacts of the sector concerned and related sectors, policy makers can direct the external funding stream in such a way as to provide wide support to regional or national economies.
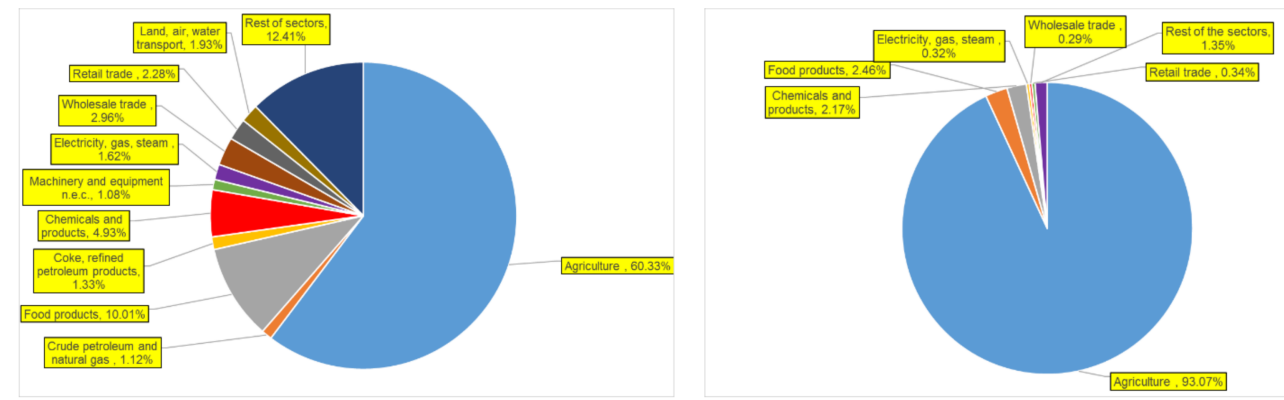

Figure 2. Percentage structure of direct and indirect impacts of the agriculture sector and related sectors in Poland (left) and the Lubelskie Region (right).

With regard to employment multipliers (type I), comparing the rankings of national bioeconomy sectors and those of the Lubelskie Region, the values are similar, with minor exceptions. Bioeconomy sectors of the Lubelskie Region, such as bio-based textiles and bio-based rubber and plastic, which are more powerful in terms of output, are also some of the most powerful in terms of employment. However, there are sectors which have, both at the national and regional levels, one of the highest employment multiplier values, e.g., the food sector. Each person employed in the food sector in Poland will create 5.5 jobs within the whole economy to cover the direct and indirect needs of this sector. In the case of the analyzed region, each person employed in the food sector will create 3.1 additional jobs. The higher value of the employment multiplier obtained for the whole country shows a smaller production and diversification of the food sector in the Lubelskie Region.

The third type of multiplier that was calculated was those reflecting the increase in household income (Type I income multipliers). Several sectors of the national bioeconomy were characterized by high household income multiplier values. We can list these as follows: bioethanol (rank = 3; value $=3.03)$, biodiesel $(4 ; 3.03)$, beverages $(8 ; 2.69)$, food products $(9 ; 2.69)$, agriculture $(10 ; 2.67)$, paper and paper products $(11 ; 2.55)$, and wood products $(12 ; 2.53)$. Taking the example of the food products sector, the value of 2.53 means that an increase of 1 million euro in the sector's income will, both directly and indirectly, increase the household income of the domestic economy by 2.53 million euro. When analyzing the household income multipliers for the regional economy, we see that only the already mentioned bio-based textiles (rank $=4$; value $=4.96$ ) and bio-based rubber and plastic $(11 ; 2.93)$ sectors are high in the ranking.

In addition to the aforementioned employment and household income multipliers, the so-called simple multipliers were also calculated for the national and regional economy. 
A simple multiplier for a given sector determines the potential of that sector to support employment or household income, according to a monetary increase in the final demand. Household income multipliers were low for both national and regional bioeconomy sectors. Regarding the employment multipliers, few sectors have relatively high values. This means that any support to these sectors will induce significant benefits for the entire economy of the country and the region. Differences between individual sectors (in terms of output, employment, and household income multipliers) of the Polish bioeconomy and the Lubelskie Region are shown in Figure 3 (below).

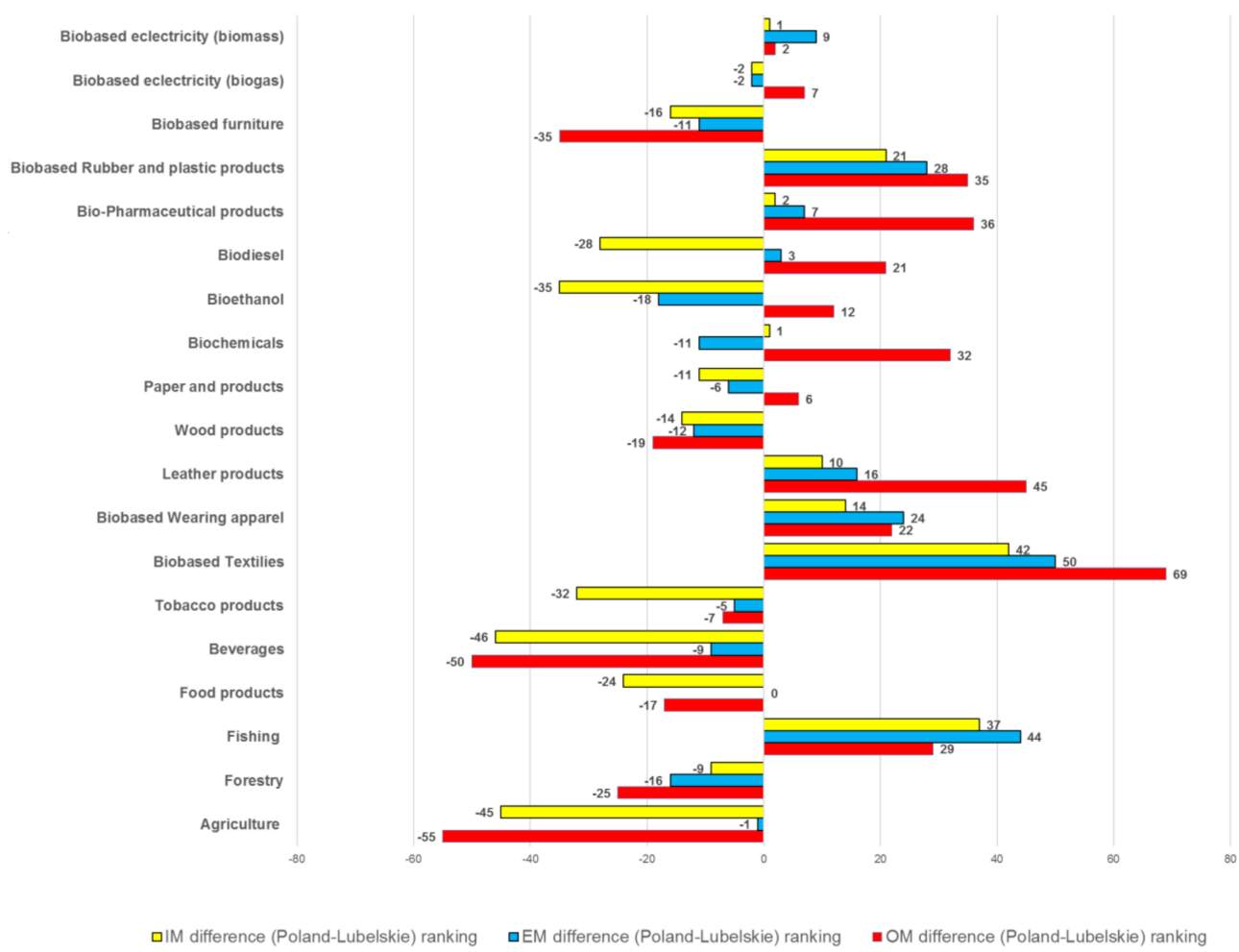

Figure 3. Difference in ranking (importance) between sectoral multipliers of the national and regional economy.

Another indicator used to measure the potential or direct and indirect linkages between sectors in the economy are the output, employment, and household income elasticities. Compared to the multipliers, the elasticity indicators take into account the size of the final demand of each sector. For both the national and the regional economies, a high value and ranking of the elasticity (output, employment, and household income) for the food sector was observed. In terms of the food sector, the output elasticity value for Poland was 0.078 (rank = 2) and for the region 0.077 (3). An exogenous change, for example, of $1 \%$, in the final demand of the food sector will increase the output of the entire national economy by $0.78 \%$ and the regional economy by $0.77 \%$. Both the food sector in the case of the national and regional economy and the agricultural sector in the case of the regional economy have great development potential. Although the output elasticities of bioeconomy sectors (pure and mixed) are relatively low, for both Poland and the Lubelskie Region, we can observe a better situation in terms of employment and household income (Table 4). 
Table 4. Input-output elasticities of the Polish and Lubelskie Region bioeconomy sectors (output, employment, and income).

\begin{tabular}{|c|c|c|c|c|c|c|c|c|c|c|c|c|c|}
\hline No. & Sector & OEP & $\mathbf{R}$ & OEL & $\mathbf{R}$ & EEP & $\mathbf{R}$ & EEL & $\mathbf{R}$ & IEP & $\mathbf{R}$ & IEL & $\mathbf{R}$ \\
\hline 1 & Agriculture & 0.024 & 15 & 0.082 & 1 & 0.016 & 37 & 0.077 & 5 & 0.035 & 9 & 0.081 & 4 \\
\hline 2 & Forestry & 0.001 & 63 & 0.003 & 54 & 0.003 & 68 & 0.004 & 72 & 0.002 & 70 & 0.004 & 73 \\
\hline 3 & Fishing & 0.000 & 77 & 0.001 & 66 & 0.001 & 77 & 0.026 & 25 & 0.002 & 72 & 0.019 & 35 \\
\hline 4 & Food products & 0.078 & 2 & 0.077 & 3 & 0.123 & 1 & 0.203 & 1 & 0.069 & 3 & 0.076 & 5 \\
\hline 5 & Beverages & 0.009 & 29 & 0.010 & 26 & 0.088 & 2 & 0.061 & 7 & 0.034 & 11 & 0.014 & 43 \\
\hline 6 & Tobacco products & 0.003 & 55 & 0.004 & 43 & 0.070 & 6 & 0.110 & 2 & 0.023 & 19 & 0.009 & 57 \\
\hline 7 & Bio-based Textiles & 0.001 & 70 & 0.000 & 75 & 0.003 & 69 & 0.007 & 62 & 0.005 & 64 & 0.051 & 13 \\
\hline 8 & Bio-based Wearing apparel & 0.004 & 50 & 0.003 & 48 & 0.007 & 60 & 0.005 & 70 & 0.008 & 57 & 0.005 & 71 \\
\hline 9 & Leather products & 0.004 & 51 & 0.005 & 42 & 0.013 & 44 & 0.014 & 43 & 0.016 & 33 & 0.012 & 48 \\
\hline 10 & Wood products & 0.008 & 34 & 0.008 & 30 & 0.010 & 49 & 0.012 & 46 & 0.014 & 39 & 0.015 & 41 \\
\hline 11 & Paper and products & 0.009 & 30 & 0.010 & 23 & 0.018 & 34 & 0.018 & 37 & 0.016 & 35 & 0.018 & 37 \\
\hline 12 & Biochemicals & 0.000 & 71 & 0.000 & 79 & 0.008 & 56 & 0.001 & 79 & 0.006 & 62 & 0.003 & 77 \\
\hline 13 & Bioethanol & 0.000 & 75 & 0.000 & 73 & 0.021 & 30 & 0.081 & 3 & 0.015 & 37 & 0.013 & 45 \\
\hline 14 & Biodiesel & 0.001 & 69 & 0.000 & 74 & 0.021 & 29 & 0.079 & 4 & 0.015 & 36 & 0.017 & 39 \\
\hline 15 & Bio-Pharmaceutical products & 0.004 & 47 & 0.002 & 61 & 0.022 & 27 & 0.028 & 23 & 0.013 & 40 & 0.010 & 56 \\
\hline 16 & Bio-based Rubber and plastic products & 0.001 & 65 & 0.000 & 76 & 0.007 & 59 & 0.012 & 45 & 0.006 & 60 & 0.028 & 24 \\
\hline 17 & Bio-based furniture & 0.009 & 28 & 0.006 & 38 & 0.017 & 35 & 0.009 & 55 & 0.021 & 26 & 0.009 & 61 \\
\hline 18 & Bio-based electricity (agriculture-biogas) & 0.000 & 78 & 0.000 & 77 & 0.025 & 17 & 0.025 & 28 & 0.012 & 43 & 0.007 & 66 \\
\hline 19 & Bio-based electricity (from biomass) & 0.000 & 76 & 0.000 & 78 & 0.025 & 20 & 0.040 & 12 & 0.012 & 44 & 0.006 & 69 \\
\hline
\end{tabular}

OEP = Output Elasticities (Poland); OML = Output Elasticities (Lubelskie Region); EEP = Employment Elasticities (Poland); EEL = Employment Elasticities (Lubelskie Region); IEP = Income Elasticities (Poland); IEL = Income Elasticities (Lubelskie Region); R = Rank.

To present the bioeconomy sectors in the context of the whole economy, both in the case of Poland and the Lubelskie region, Tables 5 and 6 are presented. The tables present the sectors that are key and most promising, in terms of output, for the development of the economy. Regarding the national economy, the food and the construction sectors are high in terms of both output multiplier and output elasticity. Regarding the Lubelskie region, the results are not uniform. Sectors with the highest output multipliers include bio-based rubber and plastic, whereas agriculture and the food sector are among the five sectors with the highest output elasticities.

Table 5. Sectors with the highest output multipliers in Poland and the Lubelskie Region $(\mathrm{OM}=$ Output Multiplier; $\mathrm{R}=$ Rank).

\begin{tabular}{cccccc}
\hline Sectors (Poland) & OM & $\mathbf{R}$ & Sectors (Lubelskie Region) & OM & $\mathbf{R}$ \\
\hline Travel agency & 2.498 & 1 & Coke, refined petroleum products & 2.225 & 1 \\
\hline Food products & 2.278 & 2 & Motor vehicles & 1.686 & 2 \\
\hline Printing and recording & 2.180 & 3 & Bio-based Rubber and Plastic products & 1.683 & 3 \\
\hline Beverages & 2.179 & 4 & Rubber and Plastic products & 1.680 & 4 \\
Construction & 2.167 & 5 & Textiles & 1.677 & 5 \\
\hline
\end{tabular}

Table 6. Sectors with the highest output elasticities in Poland and the Lubelskie Region $(\mathrm{OE}=$ Output Elasticity; $\mathrm{R}=$ Rank).

\begin{tabular}{cccccc}
\hline Sectors (Poland) & OE & $\mathbf{R}$ & Sectors (Lubelskie Region) & OE & R \\
\hline Travel agency & 2.498 & 1 & Coke, refined petroleum products & 2.225 & 1 \\
\hline Food products & 2.278 & 2 & Motor vehicles & 1.686 & 2 \\
\hline Printing and recording & 2.180 & 3 & Bio-based Rubber and Plastic products & 1.683 & 3 \\
\hline Beverages & 2.179 & 4 & Rubber and Plastic products & 1.680 & 4 \\
Construction & 2.167 & 5 & Textiles & 1.677 & 5 \\
\hline
\end{tabular}

\section{Discussion and Conclusive Remarks}

Among the bioeconomy sectors, several were included in the published input-output tables as pure sectors, and others were disaggregated from mixed sectors. Based on a 
given method, the mixed sectors of the economy were considered as follows: textiles, wearing apparel, chemicals (disaggregated from this sector: bio-chemicals, bioethanol, biodiesel), rubber and plastics, pharmaceuticals, furniture, and electricity (disaggregated from this sector: biogas, biomass). Overall, 19 bio-based sectors were extracted, indicating the percentage of biomass-based production in mixed sectors. Based on the results in Table 2 , we can observe that there is a decreasing trend (with few exceptions) in the production based on biomass, with the highest values for the European Union, similar or lower for Poland, and the lowest for the Lubelskie region. The production of biofuels for Poland and the illustrative region is not comparable to the values for the European Union, because this type of production was disaggregated differently. This study analyzed most of the bioeconomy sectors studied to date. Nevertheless, it is important to note that recently published work expands the number of sectors included as bioeconomy sectors [59].

The other objective that was accomplished in the conducted research was to examine and compare the potentials of bioeconomy sectors and the remaining sectors of the national and regional economy. This was carried out by calculating linkage coefficients for all 79 sectors. The linkage coefficients in terms of gross output, employment, and household income were used to compare the sectors of the national and regional economy. Awareness of the dynamics and the status of each sector, in particular bioeconomy sectors, allows for adequate analysis of economy-wide impacts. Analysis of the results obtained enables identification of the potential of bioeconomy sectors, in addition to identification of those that can effectively support the region's economy. This study compared the ranking of the linkage coefficients of national and regional economic sectors. The higher the ranking for a sector, the higher the multiplier. It is noticeable that the rankings for individual bioeconomy sectors of Poland and the Lubelskie Region differ in the case of output and household income multipliers. In the case of the national economy, the so-called pure (not mixed) bioeconomy sectors are more important and have a higher ranking: food products (ranking $=2$ ), beverages (4), wood products (6), and agriculture (12). The situation is the opposite in the case of the Lubelskie Region. Looking at the output multiplier, only two mixed bioeconomy sectors (bio-based textiles and bio-based rubber and plastic products) and one pure sector (the food sector) have a high ranking. National and regional bioeconomy sectors have a high employment multiplier ranking for related bioeconomy sectors. The rankings of bioeconomy sectors for household income multipliers are similar (with minor exceptions) to the rankings for output multipliers, both for Poland and for the Lubelskie Region. The derived results (rankings) for output, employment, and household income multipliers of the Polish national economy are comparable to those obtained previously [21]. Accordingly, in the case of research carried out by the Joint Research Centre, we can observe a higher relevance of pure bioeconomy sectors than of mixed bio-based sectors at the national level $[8,9,12,60]$. The development potential of individual bioeconomy sectors was also assessed by considering the size of the final demand for the sector. Elasticities' indices take this factor into account. Related bioeconomy sectors have a high ranking in the output, employment, and household income elasticities for Poland and the Lubelskie Region. Nevertheless, the Lubelskie Region has a higher potential for development in agriculture and the production of bioethanol or biodiesel. Sectors such as bio-based textiles and bio-based rubber and plastic products, which have a high ranking for multipliers in the Lubelskie Region, show a low size of final demand. On the contrary, the food sector in Lubelskie shows a relatively high ranking of multipliers and elasticities.

It is not only the economies of the Member States of the European Union that are very different from each other [60] but also the regional circumstances have a considerable influence on the diversification of economic sectors. Regarding the above, a major challenge is to develop a method which would make it possible to consistently assess the bioeconomy sectors in the national or regional level. Measures and studies estimating the share of biomass in particular economic sectors and assessing the impact of bio-economy sectors on the whole economy contribute to the development of the method. Regions are differentiated in terms of their use of natural resources, social expectations, current 
legislation, and natural or socio-economic conditions [61]. Based on the available studies, it can be concluded that there is a need for more comprehensive research on how to increase the importance of the bioeconomy in regional economies [23,61-63]. Regions, and above all local communities, can make a significant contribution to initiating and accelerating such a transformation. In particular, there is a demand for more knowledge and tailor-made research for regions in Central and Eastern Europe [23]. The same actions and strategies for the development of one region cannot usually be copied for others [62]. Any research and analysis that allows the identification of priority bioeconomy sectors, in addition to their need for funding, helps to prepare a local action strategy. Knowledge of regional resources and cross-sector synergies enables the development of the bioeconomy and the creation of added value from local biomass resources [63]. One method that enables cross-sectoral assessment of the regional economy is input-output analysis. The obtained multiplier results for the Lubelskie Region are comparable to the priorities defined in the Regional Innovation Strategy document [55]. Although the bioeconomy is considered to be a smart specialization, the role of bioeconomy sectors should be enhanced. We can observe, based on the obtained results, that the role of the bioeconomy in the Lubelskie Region is not as significant as in the case of Poland. The results obtained in the framework of the conducted analysis show the importance of a given sector in the context of the whole region's economy. They are coherent in many aspects with the results used for the development of strategic documents for the economy of the Lubelskie Region [56,64-66]. Bioeconomy sectors such as food and wood products are already important for the economy of the Lubelskie Region [64]. Other sectors, such as beverages, chemicals, pharmaceuticals, and furniture, have considerable growth potential [66]. The update of the Regional Innovation Strategy for the Lubelskie Region, in addition to other policies planned for implementation, aiming at strengthening the role of the bioeconomy in the region, should take into account the results achieved in this study as an auxiliary tool. The development of the bioeconomy in the region should be carried out by enhancing bioeconomy sectors. This can be achieved by supporting sectors with high linkage coefficients for multipliers that support the development of the bioeconomy. Supporting bioeconomy sectors with high multipliers of output, employment, and household income will have a wide impact on the region's economy. The input-output model identifies within a given economic sector the indirect effects and synergies with other economic sectors. Based on the calculated linkages between various economic sectors, local authorities can allocate support and funding (e.g., within policies or strategies) to help develop the regional bioeconomy.

Multipliers and the share of biomass in production are some of the elements that can support regional bioeconomy development planning. Other elements that should be analyzed are the structure of enterprises within the sector, economic indicators, sustainability elements, strengths and weaknesses of the sector, and the local availability of bio-based materials and technologies. It is also worth noting that this work dealt with specific bioeconomy sectors and the aspect of biomass used by these sectors. Sectors such as construction, tourism, or travel services were not analyzed. Nor did this study examine in detail the technological aspects of biomass production and recovery options, e.g., resource recovery associated with coal-combustion streams and the recovery of metals from metal-laden effluents [67]. This may be a consideration for further planned research.

Author Contributions: Conceptualization, P.J., E.L. and S.R.; Formal analysis, P.J.; Methodology, P.J. and E.L.; Resources, P.J.; Visualization, P.J.; Writing—original draft, P.J.; Writing-review \& editing, P.J., E.L. and S.R. All authors have read and agreed to the published version of the manuscript.

Funding: This work has been supported by "New Strategies on Bio-Economy in Poland-BioEcon" project, an H2020-EU project under the call: H2020 WIDESPREAD-2014-2, topic: ERA Chairs, grant agreement No 669062 and "Advancing Sustainable Circular Bioeconomy in Central and Eastern European countries: BIOEASTsUP" project, an H2020-EU project under the call: H2020-RUR-20182020/H2020-RUR-2019-1, grant agreement: 862699, at the Department of Bioeconomy and Systems Analysis, Institute of Soil Science and Plant Cultivation-State Research Institute (IUNG-PIB). 
Institutional Review Board Statement: Not applicable.

Informed Consent Statement: Not applicable.

Data Availability Statement: Not applicable.

Acknowledgments: We would like to thank Małgorzata Wydra for her help with editing the English manuscript of this paper.

Conflicts of Interest: The authors declare no conflict of interest.

\section{References}

1. Konstantinis, A.; Rozakis, S.; Maria, E.A.; Shu, K. A definition of bioeconomy through the bibliometric networks of the scientific literature. AgBioForum 2018, 21, 64-85.

2. European Commission. Strengthening the Connection between Economy, Society and the Environment; European Commission (EC): Brussels, Belgium, 2018.

3. European Commission. Review of the 2012 European Bioeconomy Strategy; European Commission (EC): Brussels, Belgium, 2017.

4. Batog, J.; Frankowski, J.; Wawro, A.; Łacka, A. Bioethanol production from biomass of selected sorghum varieties cultivated as main and second crop. Energies 2020, 13, 6291. [CrossRef]

5. Panoutsou, C.; Alexopoulou, E. Costs and profitability of crops for bioeconomy in the EU. Energies 2020, 13, 1222. [CrossRef]

6. Sefeedpari, P.; Pudełko, R.; Jędrejek, A.; Kozak, M.; Borzęcka, M. To what extent is manure produced, distributed, and potentially available for bioenergy? A step toward stimulating circular bioeconomy in Poland. Energies 2020, 13, 6266. [CrossRef]

7. Krzyżaniak, M.; Stolarski, M.J.; Graban, Ł.; Lajszner, W.; Kuriata, T. Camelina and crambe oil crops for bioeconomy-Straw utilization for energy. Energies 2020, 13, 1503. [CrossRef]

8. Ronzon, T.; Piotrowski, S.; M’Barek, R.; Carus, M. A systematic approach to understanding and quantifying the EU's bioeconomy. Bio-Based Appl. Econ.J. 2017, 6, 1-17.

9. Ronzon, T.; Piotrowski, S.; Tamosiunas, S.; Dammer, L.; Carus, M.; M'barek, R. Developments of economic growth and employment in bioeconomy sectors across the EU. Sustainability 2020, 12, 4507. [CrossRef]

10. Camia, A.; Robert, N.; Jonsson, R.; Pilli, R.; García-Condado, S.; López-Lozano, R.; van der Velde, M.; Ronzon, T.; Gurría, P.; M'Barek, R.; et al. Biomass Production, Supply, Uses and Flows in the European Union. Available online: https:/ / ec.europa.eu/jrc/en/publication/eur-scientific-and-technical-research-reports/biomass-production-supply-usesand-flows-european-union-first-results-integrated-assessment (accessed on 10 December 2020).

11. Robert, N.; Giuntoli, J.; Dos Santos Fernandes De Araujo, R.; Avraamides, M.; Balzi, E.; Barredo Cano, J.I.; Baruth, B.; Becker, W.E.; Borzacchiello, M.T.; Bulgheroni, C.; et al. Development of a bioeconomy monitoring framework for the European Union: An integrative and collaborative approach. New Biotechnol. 2020, 59, 10-19. [CrossRef] [PubMed]

12. Ronzon, T.; M'Barek, R. Socioeconomic indicators to monitor the EU's bioeconomy in transition. Sustainability $2018,10,1745$. [CrossRef]

13. European Commission. Data Portal of Agro-Economics Modelling-DataM. Available online: https://datam.jrc.ec.europa.eu/ datam/public/pages/index.xhtml?rdr=1612907882534 (accessed on 9 December 2020).

14. Kuosmanen, T.; Kuosmanen, N.; El Meligi, A.; Tevecia, R.; Gurria Albusac, P.; Iost, S.; M'Barek, R. How Big Is the Bioeconomy? Reflections from an Economic Perspective; EUR 30167 EN; JRC: Luxembourg, 2020; p. 49.

15. Efken, J.; Dirksmeyer, W.; Kreins, P.; Knecht, M. Measuring the importance of the bioeconomy in Germany: Concept and illustration. NJAS Wagenin. J. Life Sci. 2016, 77, 9-17. [CrossRef]

16. Blumberga, D.; Indzere, Z.; Muizniece, I.; Blumberga, A.; Bauzbers, G.; Gravelins, A. Why bioeconomy is actual for Latvia. Research achievements in institute of energy systems and environment. Energy Procedia 2017, 113, 460-465. [CrossRef]

17. Runge, K.; Blumberga, A.; Blumberga, D. Bioeconomy growth in Latvia. System-dynamics model for high-value added products in fisheries. Energy Procedia 2017, 113, 339-345. [CrossRef]

18. Haapala, A.; Härkönen, J.; Leviäkangas, P.; Kess, P.; Häggman, H.; Arvola, J.; Stoor, T.; Ämmälä, A.; Karppinen, K.; Leppilampi, M.; et al. Bioeconomy potential-Focus on Northern Finland. Int. J. Sustain. Econ. 2015, 7, 66-90. [CrossRef]

19. Lainez, M.; Gonzalez, J.M.; Aguilar, A.; Vela, C. Spanish strategy on bioeconomy: Towards a knowledge based sustainable innovation. New Biotechnol. 2018, 40, 87-95. [CrossRef]

20. Grealis, E.; O'Donoghue, C. The Economic Impact of the Irish Bio-Economy-Bio-Economy Input-Output Model: Development and Uses. TEAGASC Report. Available online: https:/ /www.teagasc.ie/publications/2015/the-economic-impact-of-the-irishbio-economy---the-bio-economy-input-output-model-development-and-uses.php (accessed on 11 December 2020).

21. Loizou, E.; Jurga, P.; Rozakis, S.; Faber, A. Assessing the potentials of bioeconomy sectors in Poland employing input-output modeling. Sustainability 2019, 11, 594. [CrossRef]

22. Iammarino, S.; Rodríguez-Pose, A.; Storper, M. Why Regional Europe's Economic Matters for Development Future. Available online: https:/ / ec.europa.eu/regional_policy/sources/docgener/work/201707_regional_development_matters.pdf (accessed on 9 December 2020).

23. Haarich, S. Bioeconomy Development in EU Regions-Final Report. Available online: https://ec.europa.eu/research/ bioeconomy/pdf/publications/bioeconomy_development_in_eu_regions.pdf (accessed on 8 December 2020). 
24. De Besi, M.; McCormick, K. Towards a bioeconomy in Europe: National, regional and industrial strategies. Sustainability 2015, 7, 10461-10478. [CrossRef]

25. Lehtonen, O.; Okkonen, L. Regional socio-economic impacts of decentralized bioeconomy: A case of Suutela wooden village, Finland. Environ. Dev. Sustain. 2013, 15, 245-256. [CrossRef]

26. Zawalińska, K.; Rok, J. Wojewódzkie tablice przepływów międzygałęziowych dla Polski: Konstrukcja i interpretacja. Studia Reg. Lokalne 2017, 69, 29-53.

27. International Advisory Council on Global Bioeconomy. Global Bioeconomy Policy Report (IV): A Decade of Bioeconomy Policy Development around the World. Available online: https:/ / knowledge4policy.ec.europa.eu/publication/global-bioeconomypolicy-report-iv-decade-bioeconomy-policy-development-around-world_en (accessed on 11 December 2020).

28. European Commission. Policy Measures Taken against the Spread and Impact of the Coronavirus-8 December 2020. Available online: https:/ / ec.europa.eu/info/sites/info/files / coronovirus-policy-measures-8-december_en.pdf (accessed on 9 December 2020).

29. Kuckertz, A.; Brändle, L.; Gaudig, A.; Hinderer, S.; Reyes, C.A.M.; Prochotta, A.; Steinbrink, K.M.; Berger, E. Startups in times of crisis-A rapid response to the COVID-19 pandemic. J. Bus. Ventur. Insights 2020, 13, e00169. [CrossRef]

30. European Commission. Establishing a European Union Recovery Instrument to Support the Recovery in the Aftermath of the COVID-19 Pandemic. Available online: https:/ / eur-lex.europa.eu/legal-content/EN/TXT/?uri=CELEX\%3A52020PC0441R\%28 01\%29 (accessed on 7 December 2020).

31. Antošová, G.; Vogl, M.; Schraud, M. Challenges for the Visegrad Group-The coronavirus crises and its impact on tourism. Visegr. J. Bioecon. Sustain. Dev. 2020, 9, 1. [CrossRef]

32. Duan, H.; Wang, S.; Yang, C. Coronavirus: Limit Short-Term Economic Damage. Available online: https://www.nature.com/ articles/d41586-020-00522-6 (accessed on 6 December 2020).

33. Inoue, H.; Todo, Y. The Propagation of the Economic Impact through Supply Chains: The Case of a Mega-City Lockdown against the Spread of COVID-19. Available online: https://journals.plos.org/plosone/article?id=10.1371/journal.pone.0239251 (accessed on 8 December 2020).

34. Lenzen, M.; Li, M.; Malik, A.; Pomponi, F.; Sun, Y.; Wiedmann, T.; Faturay, F.; Fry, J.; Gallego, B.; Geschke, A.; et al. Global socio-economic losses and environmental gains from the coronavirus pandemic. PLoS ONE 2020, 15, e0235654. [CrossRef] [PubMed]

35. Loizou, E.; Chatzitheodoridis, F.; Michailidis, A.; Tsakiri, M.; Theodossiou, G. Linkages of the energy sector in the Greek economy: An input-output approach. Int. J. Energy Sect. Manag. 2015, 9, 3. [CrossRef]

36. Miller, R.E.; Blair, P.D. Input-Output Analysis: Foundations and Extensions, 2nd ed.; Oxford University Press: London, UK, 2009.

37. Masera, R. For a resilient, sustainable and inclusive recovery in Europe: Challenges and proposals in response to the pandemic crisis. Law Econ. Yrly. Rev. 2020, 9, 61-80. [CrossRef]

38. Reilly, J.M.; Chen, Y.-H.H.; Jacoby, H.D. The COVID-19 effect on the Paris agreement. Humanit. Soc. Sci. Commun. 2021, 8, 16. [CrossRef]

39. Kulišić, B.; Loizou, E.; Rozakis, S.; Šegon, V. Impacts of biodiesel production on Croatian economy. Energy Policy 2007, 35, 6036-6045. [CrossRef]

40. Vale, M.; Pantalone, M.; Bragagnolo, M. Collaborative perspective in bio-economy development: A mixed method approach. In Collaboration in a Data-Rich World, Proceedings of the Working Conference on Virtual Enterprises, PRO-VE 2017, Vicenza, Italy, 18-20 September 2017; Camarinha-Matos, L., Afsarmanesh, H., Fornasiero, R., Eds.; IFIP Advances in Information and Communication Technology; Springer: Cham, Switzerland, 2017; p. 506.

41. Liu, L.; Huang, G.; Baetz, B.; Cheng, G.; Pittendrigh, S.M.; Pan, S. Input-output modeling analysis with a detailed disaggregation of energy sectors for climate change policy-making: A case study of Saskatchewan, Canada. Renew. Energy 2020, 151, 1307-1317. [CrossRef]

42. Towa, E.; Zeller, V.; Achten, W. Input-output models and waste management analysis: A critical review. J. Clean. Prod. 2020, 249, 119359. [CrossRef]

43. Ali, Y.; Bilal, M.; Sabir, M. Impacts of transport strike on Pakistan economy: An Inoperability Input-Output Model (IIOM) approach. Res. Transp. Econ. 2020. [CrossRef]

44. Tabatabaie, S.M.H.; Murthy, G.S. Development of an input-output model for food-energy-water nexus in the Pacific Northwest. Resour. Conserv. Recycl. 2020. [CrossRef]

45. Loizou, E.; Karelakis, C.; Galanopoulos, K.; Mattas, K. The role of agriculture as a development tool for a regional economy. Agric. Syst. 2019, 173, 482-490. [CrossRef]

46. Lampiris, G.; Karelakis, C.; Loizou, E. Comparison of non-survey techniques for constructing regional input-output tables. Ann. Oper. Res. 2019, 294, 225-266. [CrossRef]

47. Karelakis, C.; Loizou, E.; Chatzitheodoridis, F.; Mattas, K. Assessing policy impacts on the economy of European insular rural regions: The case of the smaller Aegean Islands programme. Eur. Plan. Stud. 2020, 28, 1771-1789. [CrossRef]

48. Mattas, K.; Loizou, E.; Tzouvelekas, V. Rural development through input-output modelling. In Advances in Modelling Agricultural Systems; Papajorgji, P.J., Pardalos, P.M., Eds.; Springer: Boston, MA, USA, 2009.

49. Mattas, K.; Loizou, S.; Tzouvelekas, V.; Tsakiri, M.; Bonfiglio, A. Deriving regional I-O tables and multipliers. In Rural Balkans and EU Integration: An Input-Output Approach; Bonfiglio, A., Esposti, R., Sotte, F., Eds.; FrancoAngeli: Milan, Italy, 2006. 
50. Jensen, R.C.; Mandeville, T.D.; Karunaratne, N.D. Regional Economic Planning: Generation of Regional Input-Output Analysis; Croom Helm: London, UK, 1979.

51. Flegg, A.T.; Tohmo, T. Regional input-output tables and the FLQ formula: A case study of Finland. Reg. Stud. 2013, 47, 703-721. [CrossRef]

52. Flegg, A.T.; Mastronardi, L.J.; Romero, C.A. Evaluating the FLQ and AFLQ formulae for estimating regional input coefficients: Empirical evidence for the province of Córdoba, Argentina. Econ. Syst. Res. 2016, 28, 21-37. [CrossRef]

53. Flegg, A.T.; Tohmo, T. The regionalization of national input-output tables: A study of South Korean regions. Pap. Reg. Sci. 2018, 98, 601-620. [CrossRef]

54. Markowski, K.; Dymek, W.; Dziaduch, S.; Kurlej, Z.; Łoś, E.; Matacz, A.; Olszewska-Welman, A.; Tucki, K.; Wroński, P. Lubelskie Voivodship. 2016. Available online: https://lublin.stat.gov.pl/en/publications/statistical-yearbook/lubelskie-voivodshipsubregions-powiats-gminas-2016,2,13.html (accessed on 8 December 2020).

55. Kociuba, D. Regional innovation strategy—From design to implementation. Lubelskie Voivodship case study. Barom. Reg. Anal. Progn. 2017, 2, 99-114.

56. Marshal Office of the Lubelskie Voivodship in Lublin. Regional Innovation Strategy for the Lubelskie Voivodeship. 2020. Available online: http://www.onlines3.eu/wp-content/uploads/RIS3_strategy_repository/PL_Regional_Innovation_Strategy_ of_Lubelskie_Voivodeship_2020.pdf (accessed on 9 December 2020).

57. Gembarzewska, H.; Grabani, P.; Kaczyńska-Beliniak, D.; Rymarczyk, P.; Skwara, P.; Soroczyńska, E.; Tarnowski, K. Input-Output Table at Basic Prices in 2015. Available online: https:/ /stat.gov.pl/en/topics/national-accounts/annual-national-accounts/ input-output-table-at-basic-prices-in-2015,5,3.html (accessed on 7 December 2020).

58. Garnuszek, M.; Zgierska, A. Employment in National Economy. 2015. Available online: http://stat.gov.pl/obszary-tematyczne/ rynek-pracy/pracujacy-zatrudnieni-wynagrodzenia-koszty-pracy/ (accessed on 7 December 2020).

59. Kardung, M.; Cingiz, K.; Costenoble, O.; Delahaye, R.; Heijman, W.; Lovrić, M.; van Leeuwen, M.; M’Barek, R.; van Meijl, H.; Piotrowski, S.; et al. Development of the circular bioeconomy: Drivers and indicators. Sustainability 2021, 13, 413. [CrossRef]

60. Philippidis, G.; Ferrari, E.; M’barek, R.; Sanjuán, E.I. Structural Patterns of Bioeconomy in the EU Member States-A SAM Approach. Available online: https:/ / ec.europa.eu/jrc/en/publication/eur-scientific-and-technical-research-reports/structuralpatterns-bioeconomy-eu-member-states-sam-approach (accessed on 10 December 2020).

61. Lier, M.; Kärkkäinen, L.; Korhonen, K.T.; Packalen, T. Understanding the Regional Bioeconomy Settings and Competencies in 29 EU Regions in 11 EU Countries. Available online: https://jukuri.luke.fi/handle/10024/545184 (accessed on 9 December 2020).

62. Charles, D.; Davies, S.; Miller, S.; Clement, K.; Hoes, A.; Hasenheit, M.; Kah, S.; Bianchini, C.; Clement, K.; Overbeek, G.; et al. Case Studies of Regional Bioeconomy Strategies across Europe. Available online: http:/ /www.bio-step.eu/fileadmin/BioSTEP/ Bio_documents/BioSTEP_D3.2_Case_studies_of_regional_strategies.pdf (accessed on 10 December 2020).

63. German Bioeconomy Council. A Report from the German Bioeconomy Council Bioeconomy Policy (Part III) Update Report of National Strategies around the World. Available online: https:/ / knowledge4policy.ec.europa.eu/publication/bioeconomypolicy-part-iii-update-report-national-strategies-around-world_en (accessed on 10 December 2020).

64. Lublin Municipal Office's Investor Relations. Invest in Lublin. Available online: https://www.invest-in-lublin.com/key-sectors (accessed on 10 March 2021).

65. AgroRES Interreg Europe. Lubelskie Voivodeship. Available online: https://www.interregeurope.eu/agrores/news/newsarticle/7961/lubelskie-voivodeship/ (accessed on 10 March 2021).

66. Strategia Rozwoju Województwa Lubelskiego na Lata 2014-2020 (z Perspektywa do 2030 Roku). Available online: https: / / strategia.lubelskie.pl/ogloszenie/srwl.projekt.2021.02.02.pdf (accessed on 10 March 2021).

67. Staicu, L.C.; Wojtowicz, P.; Pósfai, M.; Pekker, P.; Gorecki, A.; Jordan, F.; Barton, L. PbS biomineralization using cysteine: Bacillus cereus and the sulfur rush. FEMS Microbiol. Ecol. 2020, 96, 9. [CrossRef] 